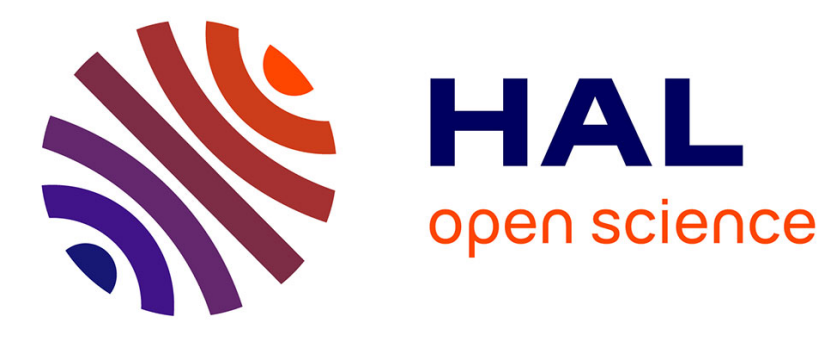

\title{
High Temperature Oxidation of Slurry Aluminized Deformable Austempered Ductile Iron (DADI)
}

Olga Tsurtsumia, Fernando Pedraza, Benjamin Gregoire, Nugzar Khidasheli, Elguja Kutelia

\section{- To cite this version:}

Olga Tsurtsumia, Fernando Pedraza, Benjamin Gregoire, Nugzar Khidasheli, Elguja Kutelia. High Temperature Oxidation of Slurry Aluminized Deformable Austempered Ductile Iron (DADI). Metallurgical and Materials Transactions A, 2020, 51 (2), pp.920-926. 10.1007/s11661-019-05576-4 . hal02466258

\section{HAL Id: hal-02466258 \\ https://hal.science/hal-02466258}

Submitted on 4 Feb 2020

HAL is a multi-disciplinary open access archive for the deposit and dissemination of scientific research documents, whether they are published or not. The documents may come from teaching and research institutions in France or abroad, or from public or private research centers.
L'archive ouverte pluridisciplinaire HAL, est destinée au dépôt et à la diffusion de documents scientifiques de niveau recherche, publiés ou non, émanant des établissements d'enseignement et de recherche français ou étrangers, des laboratoires publics ou privés. 


\title{
High Temperature Oxidation of Slurry Aluminized Deformable Austempered Ductile Iron (DADI)
}

\author{
Olga Tsurtsumia ${ }^{\mathrm{a}}$, Fernando Pedraza ${ }^{\mathrm{b}^{*}}$, Benjamin Gregoire ${ }^{\mathrm{b}}$, Nugzar Khidasheli ${ }^{\mathrm{a}}$, Elguja \\ Kutelia $^{\mathrm{a}}$
}

${ }^{a}$ Republic Center for Structure Research, Georgian Technical University, 77 Kostava Street, 0175, Tbilisi, GEORGIA

${ }^{b}$ Laboratoire des Sciences de l'Ingénieur pour l'Environnement (LaSIE, UMR-CNRS 7356), Université de La Rochelle, Avenue Michel Crépeau, 17042 La Rochelle Cedex 1, FRANCE * corresponding author: fpedraza@univ-lr.fr

\begin{abstract}
This work reports on the aluminization and oxidation behaviour of a new class of cast iron (Deformable Austempered Ductile Iron, DADI). The slurry aluminization resulted in uneven coatings due to the lack of wettability of molten aluminium to the graphite inclusions of the substrate. In spite of this, the isothermal tests at $650^{\circ} \mathrm{C}$ for $100 \mathrm{~h}$ in air revealed a drastic reduction of oxygen uptake related to the formation of mixed Al-containing spinels compared to the very unprotective iron oxides formed in the absence of coating. It derives that deposition of thicker aluminide layers by precoating with e.g. nickel would be a promising way to protect further DADI cast iron.
\end{abstract}

Keywords: DADI, Slurry aluminization, interdiffusion zone, HT oxidation resistance

\section{INTRODUCTION}

The low density Deformable Austempered Ductile Iron (DADI) has been designed to exhibit outstanding mechanical properties including high strength and toughness and good wear resistance, possibility to control its hardness values and easy machinability [1-3]. Therefore, DADI has potential applications for different engineering fields like in the automotive sector as a worthy substitution to the more costly steels [4-5]. However, its behaviour at high temperatures has not been studied yet because the formation of unprotective iron oxides is anticipated in relation to its chemical composition (Fe, 3.6 C, $2 \mathrm{Al}, 0.8 \mathrm{Si}, 0.4 \mathrm{Mn}, 0.04 \mathrm{Mg}$, wt $\%$ ). Further, the graphite inclusions derived from the very high $\mathrm{C}$ content (up to $4 \mathrm{wt} \%$ ) can 
be burnt by oxidation and provide easy paths for oxidation towards the deeper layers of the matrix. However, except for the recent works of Wang et al. on the pack aluminizing cast iron [6] such phenomena have been rarely reported in the open literature, which is part of this investigation.

Kiani Rashid and Edmonds demonstrated that the addition of Al to the bulk ductile cast alloy could increase the oxidation resistance while improving the resistance to decarburization at $550^{\circ} \mathrm{C}$ [7]. However, increasing the amount of $\mathrm{Al}$ makes casting of the alloy quite complex. Therefore, it derives that the application of a protective Al-containing coating could improve the oxidation behaviour of DADI. Among the different coating alternatives, slurry aluminizing has been proven as an alternative to other aluminizing techniques like pack cementation. The mechanisms of formation of these coatings have been thoroughly described on different metal substrates like pure Ni [8], different steels [9,10] and Ni-based alloys [11]. Depending on the amount of slurry deposited and on the annealing treatment, FeAl-based intermetallics can be obtained [12], which are reported to resist oxidation in a wide range of temperatures [13]. Therefore, this work reports on the aluminization of DADI steel and on its subsequent oxidation behaviour at high temperatures.

\section{EXPERIMENTAL PROCEDURE}

Rectangular shaped coupons of DADI with approximate dimensions $15 \times 15 \times 5 \mathrm{~mm}$ were cut from the casted ingots of the chemical composition $\mathrm{Fe}, 3.6 \mathrm{C}, 2 \mathrm{Al}, 0.8 \mathrm{Si}, 0.4 \mathrm{Mn}, 0.04 \mathrm{Mg}$ (wt \%). Two types of DADI steels were studied, the as-casted and the thermally treated one. For the latter, the samples went through austenization at up to $900^{\circ} \mathrm{C}$ in air for 20 minutes and subsequently quenched in water. They were then tempered at $380^{\circ} \mathrm{C}$ and $270^{\circ} \mathrm{C}$ for respectively, 2 and 3 hours to relax stresses and to obtain a fine-grained structure [4, 5]. Regardless of the annealing treatment, the main feature of DADI's microstructure is the presence of coarse spheroidized graphite shown in Fig. 1. All the specimens were polished with SiC P180, washed in alcohol, thoroughly dried and weighed before application of the slurry coating by spray. 


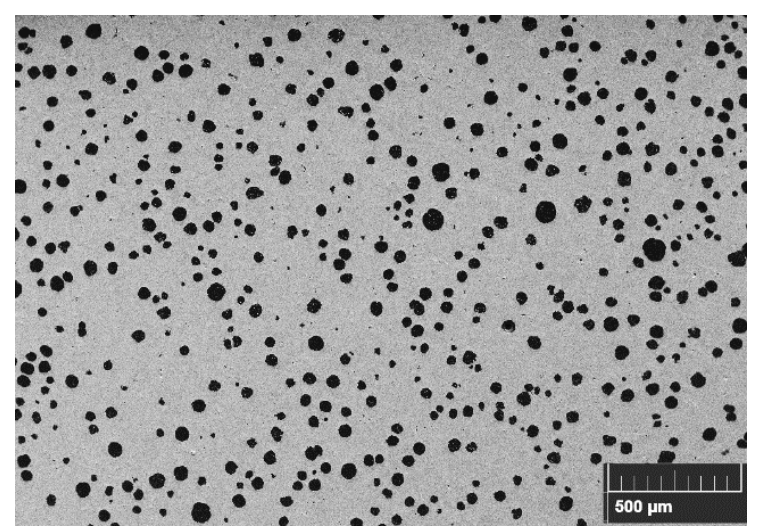

FIGURE 1. Polished surface of DADI showing the graphite nodules in the iron matrix (optical microscopy).

The aluminium-containing slurry was prepared following the procedure previously reported [8, 11, 14]. Namely, polyvinyl alcohol (PVA, Sigma Aldrich, Mowiol 4-88) powder was dissolved in deionised water with 1:10 proportion and stirred thoroughly while heated up to $90^{\circ} \mathrm{C}$. Then, Al powder (Hermillon, ULT0665 Ø5-7 $\mu \mathrm{m}$ ) was added with a ratio of 1 to 1.3 to form an even suspension by stirring. The main surfaces of the DADI samples were then coated by airbrush with $10 \mathrm{mg} / \mathrm{cm}^{2}$ of slurry. After drying in air, the coated samples were annealed under flowing $\operatorname{Ar}(\mathrm{g})$ at $400^{\circ} \mathrm{C} / 3 \mathrm{~h}+650^{\circ} \mathrm{C} / 3 \mathrm{~h}$ and $900^{\circ} \mathrm{C} / 0 \mathrm{~h}$ and then cooled to room temperature. After annealing, the coated surfaces were grit blasted lightly to remove the residues left by the slurry (bisque).

The high temperature oxidation tests of the uncoated and the slurry aluminized DADI specimens were performed in laboratory air at $650^{\circ} \mathrm{C}$ for 100 hours. Two samples of each kind were weighed, removed at different times, weighed again and introduced back in the furnace till time completion $(100 \mathrm{~h})$. The average weight gains were then plotted as a function of oxidation time. The surfaces and cross-sections were characterized by SEM/EDS (FEI Quanta 200F Field Emission Gun coupled to an EDAX detector operating at $20 \mathrm{kV}$ and WD $=10 \mathrm{~mm}$ ). Both secondary electron (mostly for the surfaces) and backscattered electron (cross-section) images were collected. The X-ray diffraction was performed in a Bruker AXS D8 Advance apparatus using $\lambda_{\mathrm{Cu}}$ radiation.

\section{RESULTS}




\subsection{Surface slurry aluminization}

After annealing of the coating, the slurry residue (bisque) detaches off. This allows to observe the coated substrate with a mat contrast. The residue has formed a very thin layer that can be manipulated with care for analysis. Fig. 2 gathers the SEM images of the surface of the slurry residue (Fig. 2a), the back side of the residue formerly in contact with the substrate (Fig. 2b), the surface of the coated specimen (Fig. 2c) and the corresponding cross-section. At the surface of the residue (Fig. 2a) the spherical shape of the Al particles can still be observed. In contrast, the back side (Fig. 2b) appears very uneven with open-like particles. In addition, coarse semitransparent features occur throughout this internal surface. The surface of substrate looks also heterogeneous with irregular small nodules and dark and smooth hexagonal shapes. The EDS composition analyses on the different areas are given in Table 1.
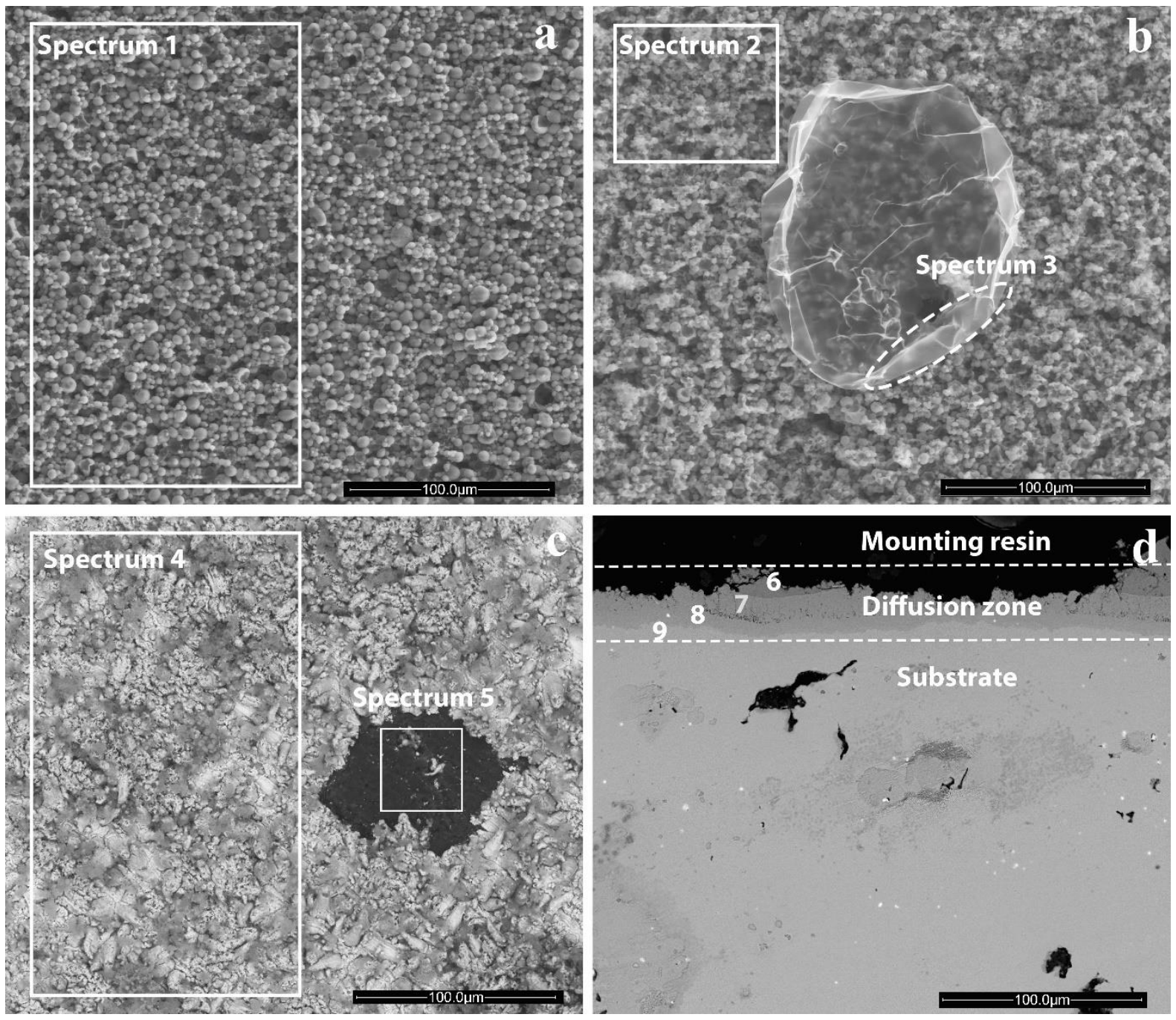

FIGURE 2. SEM images of the top and the bottom surfaces (a and b, SE images) of the slurry residue (bisque) detached from the slurry aluminized DADI substrate (c) and cross section of as aluminized specimen (d) (BS images). 
The top and the bottom of the slurry residue (bisque) are solely composed of $\mathrm{Al}$ and of $\mathrm{O}$, with relatively similar amounts. The transparent deposit of Fig. $2 \mathrm{~b}$ contains about $9 \mathrm{wt} \% \mathrm{C}$ in addition to $\mathrm{Al}$ and $\mathrm{O}$ but these values are quite approximate because of the thinness of this layer and the inaccuracy of EDS to determine this light element. The surface of the coating is rich in $\mathrm{Fe}$ and in $\mathrm{Al}$, whose ratio reminds of a mixture of $\mathrm{FeAl}$ and $\mathrm{Fe}_{2} \mathrm{Al}_{5}$ according to the $\mathrm{Al}-\mathrm{Fe}$ binary phase diagram at $900^{\circ} \mathrm{C}$ [15] but these elements appear to be oxidized. The dark hexagonal features are characterized by a very high content of $\mathrm{C}$.

The EDS analyses of the cross-section (Figure 2d) indicate a progressive decrease of $\mathrm{Al}$ and a countercurrent increase of $\mathrm{Fe}$ that suggest the formation of mixed $\mathrm{Fe}_{2} \mathrm{Al}_{5}$ and $\mathrm{FeAl}$ at the external side of the coating and the progressive dissolution of $\mathrm{Al}$ in the $\mathrm{Fe}$ matrix till $\alpha-\mathrm{Fe}(\mathrm{Al})$.

Table I. Average composition (wt\%) of the main elements obtained by EDS in the areas marked on Figure 2.

\begin{tabular}{|l|c|c|c|c|c|}
\hline & Fe & Al & O & C & Si \\
\hline $\mathbf{1}$ (top of the bisque) & - & 79.1 & 20.9 & - & - \\
\hline $\mathbf{2}$ (bottom of the bisque) & - & 83.7 & 16.3 & - & - \\
\hline $\mathbf{3}$ (transparent deposit) & - & 58.2 & 32.8 & 8.9 & - \\
\hline $\mathbf{4}$ (coating surface) & 56.9 & 31.7 & 11.3 & - & 0.2 \\
\hline $\mathbf{5}$ (hexagonal feature) & 8.7 & 3.2 & 6.2 & 81.8 & 0.1 \\
\hline $\mathbf{6}$ (Al zone, cross section) & 50.3 & 48.8 & - & - & - \\
\hline $\mathbf{7}$ (Al zone, cross section) & 64.1 & 34.3 & - & - & 0.6 \\
\hline $\mathbf{8}$ (Al zone, cross section) & 73.9 & 25.5 & - & - & 0.4 \\
\hline $\mathbf{9}$ (Al zone, cross section) & 86.1 & 13.3 & - & - & 0.3 \\
\hline
\end{tabular}

The SEM and the EDS analyses demonstrate that the thickness of the coating reached about 30 $\mu \mathrm{m}$ of depth. However, whereas the coating/substrate interface is relatively even, the surface of the coating is rather irregular and prompted with graphite inclusions. Therefore, more global analyses were performed by XRD. The patterns of the as-coated and the as-received substrate are compared in Figure 3. It can be observed that the X-ray patterns of the as-received DADI (similar pattern for the uncoated and annealed samples) display the main typical reflections associated with the body centred cubic structure of $\mathrm{Fe}(\alpha-\mathrm{Fe})$. In addition, some minor peaks 
seem to belong to hexagonal graphite. In the aluminized specimens, the three main reflections can also be related to body centred cubic structure but their shift with respect the as-received material indicate that they may belong to $\mathrm{B} 2-\mathrm{FeAl}$, which is also in line with the EDS analysis. The remaining peaks belong mostly to different diffraction planes of the orthorhombic $\mathrm{Fe}_{2} \mathrm{Al}_{5}$ [16].

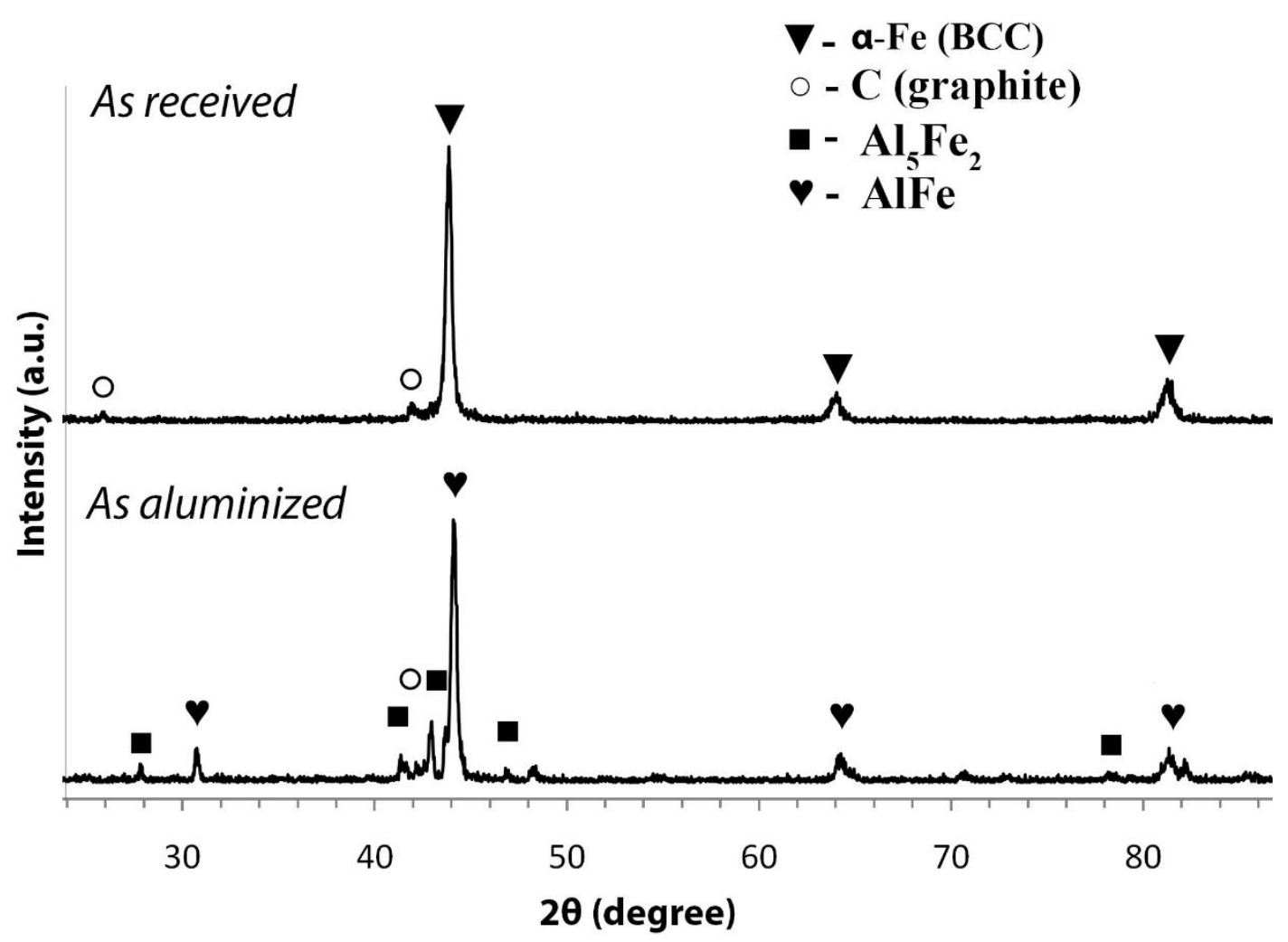

FIGURE 3. XRD patterns of the as-received and as-aluminized DADI samples.

\subsection{High temperature oxidation experiments}

All the coated samples were grit blasted to remove the superficial remnants of the slurry prior to the oxidation experiments. The evolution of the specific mass gain with exposure to air at $650^{\circ} \mathrm{C}$ is plotted in Figure 4. Because of the limited availability of samples, no reproducibility results are shown and therefore, no oxidation kinetics will be discussed. The data displayed are thus comparative. However, it can be readily observed that the uncoated DADI steel undergoes a much greater mass gain than any of the aluminized specimens irrespective whether the substrate had been previously thermally treated or not. The differences between these two aluminized substrates occur at the beginning of the oxidation tests where some mass losses are recorded for the non-annealed DADI with respect the annealed one. 


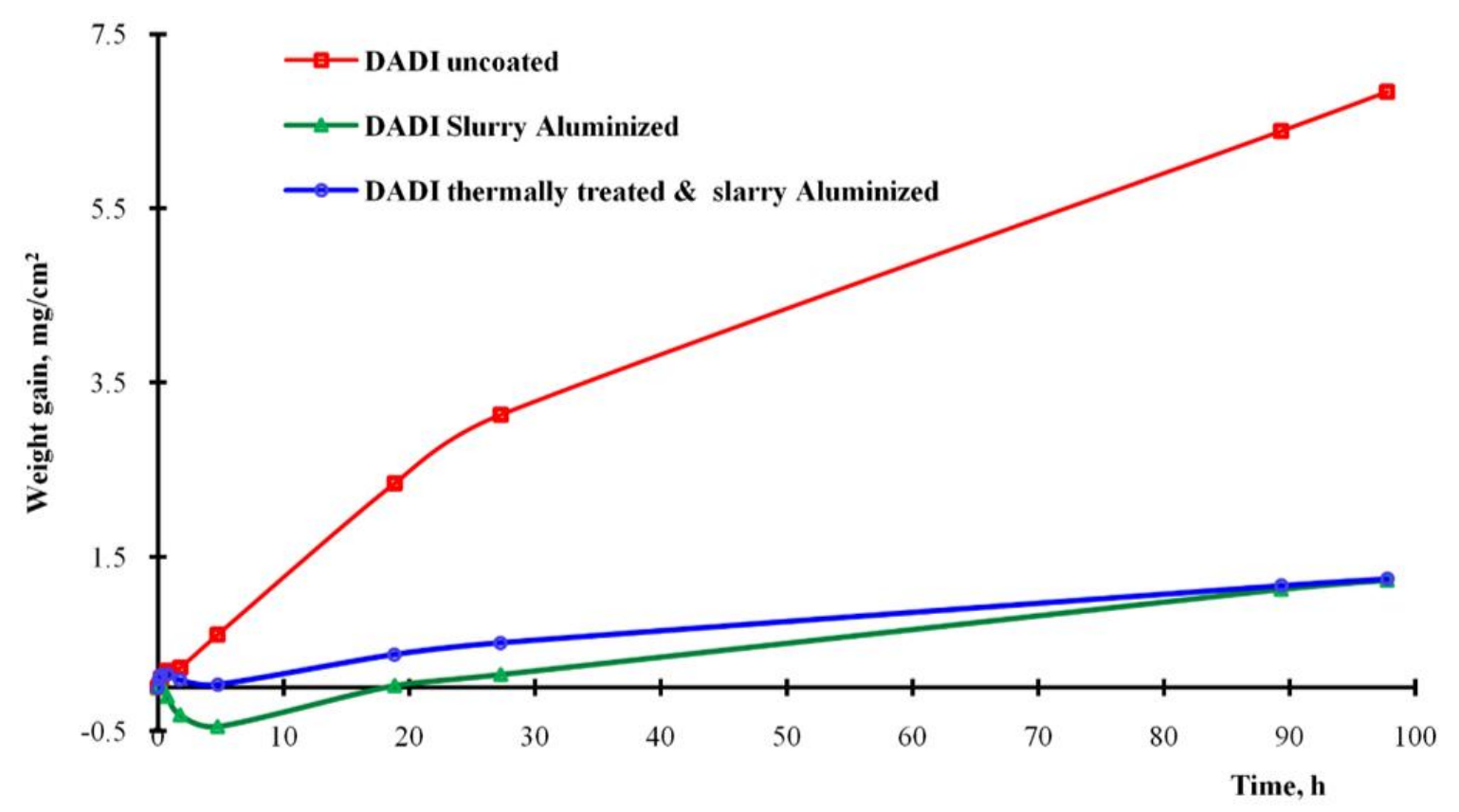

FIGURE 4. Evolution of the specific mass gain with oxidation for 100 hat $650^{\circ} \mathrm{C}$ in air.

Figure 5 shows the surface and the cross-sections of the uncoated and coated samples after the overall exposure of $100 \mathrm{~h}$ at $650^{\circ} \mathrm{C}$ in air. The EDS elemental compositions obtained from the marked areas on SEM images are given in table 2. Figures $5 \mathrm{a}$ and $5 \mathrm{~b}$ exhibit, respectively, the top surface and the cross section of the uncoated DADI after its high temperature oxidation. The surface of the uncoated substrate is very uneven and shows different contrast in the backscattered electron mode. The dark round shapes contain Fe, O and some Si but no C. The composition of the bright oxide scale is similar to the dark one but without Si. In the crosssection, a dual-layered scale of about $65 \mu \mathrm{m}$ has grown. The outer subscale is more porous than the internal one, which is typical of the external $\mathrm{Fe}_{2} \mathrm{O}_{3}$ and internal $\mathrm{Fe}_{3} \mathrm{O}_{4}$ layers formed on pure Fe [17]. In some other areas, the initial graphite nodules got completely oxidized in a very similar manner as those of the aluminized samples (Fig. 5c to 5f) and are thus not shown. The aluminized samples do not show any particular difference between the not annealed and the thermally treated samples after oxidation. The surface and the cross-sections are characterized by the presence of various nodules of different shape but little difference in composition. For instance, the dark nodules contain somewhat more Al than the bright ones but are all mainly composed of $\mathrm{Fe}$ and of $\mathrm{O}$. Such nodules grow between relatively even oxide scales. The oxide scales are very thin according to the little content of $\mathrm{O}$ analyzed by EDS and the corresponding SEM cross-sections. These cross-sections clearly show that the coating thickness and composition have barely evolved with oxidation at $650^{\circ} \mathrm{C}$. However, the areas where the graphite nodules were present are now heavily oxidized with different oxide phases according 
to the different contrast of the backscattered electrons and the EDS analyses of Table 2. The outermost areas are solely composed of $\mathrm{Fe}$ and $\mathrm{O}$ with no Al. In contrast, the internal zones of the nodules are comparatively much less oxidized. The interface between the nodules and the substrate contain some $\mathrm{Al}$ (spots 6, 7 and 8 in Table 2).

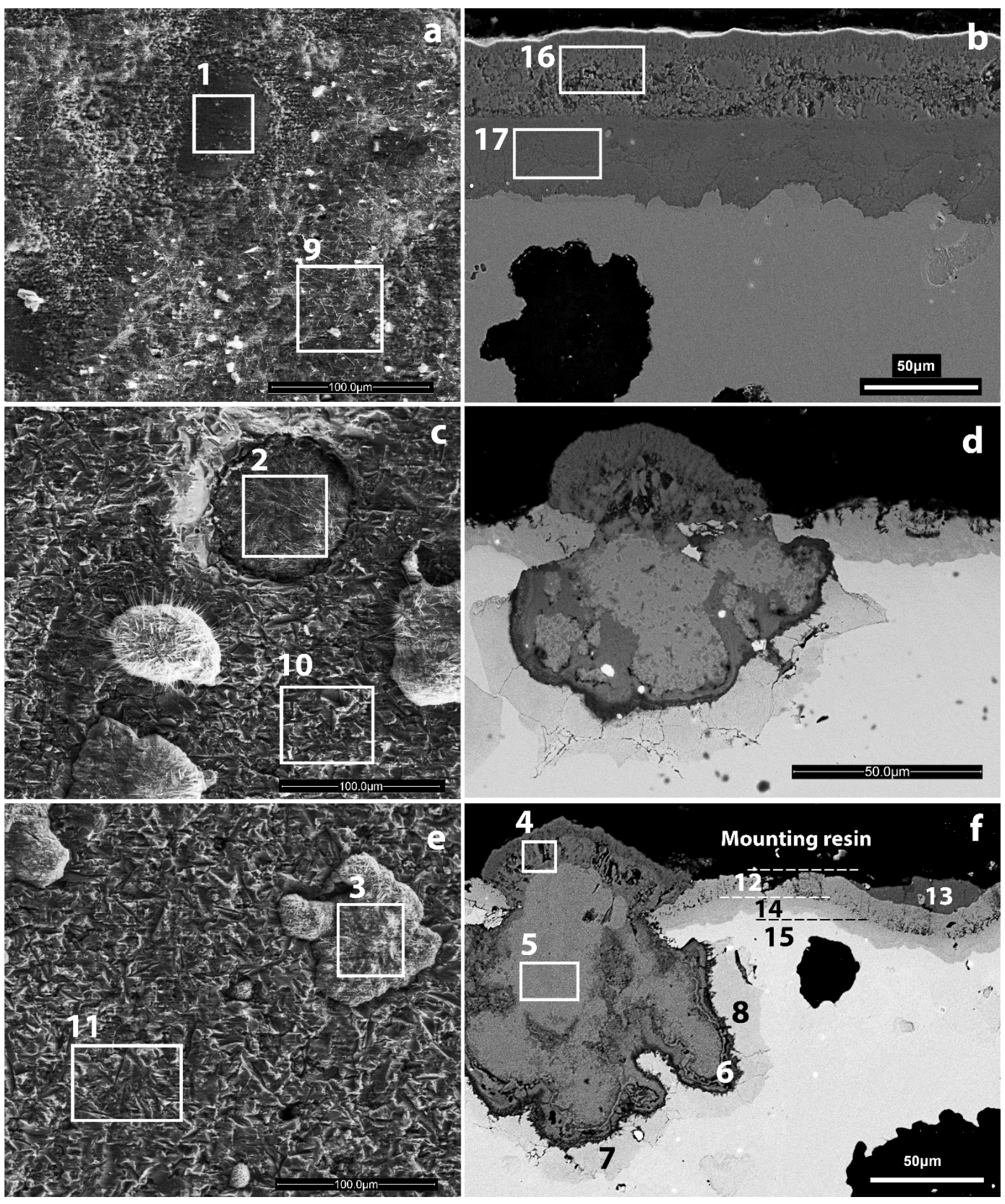

FIGURE 5. SEM images of top (a, c, e SE images) and cross section views (b, d, f BS images) corresponding to the uncoated and the aluminized not annealed and thermally treated DADI 
samples, respectively after oxidation in air at $650^{\circ} \mathrm{C}$ for 100 hours (the elemental composition obtained by EDS from marked areas are given in Table2).

Table II. EDS analyses (wt. \%) of the different areas marked in Figure 5.

\begin{tabular}{|l|c|c|c|c|}
\hline & Fe & Al & $\mathbf{O}$ & Si \\
\hline Spectrum 1 (Nodule) & 73.98 & - & 25.89 & 0.13 \\
\hline Spectrum 2 (Nodule) & 67.42 & 10.49 & 21.98 & 0.11 \\
\hline Spectrum 3(Nodule) & 69.43 & 6.54 & 23.34 & - \\
\hline Spectrum 4 & 70.50 & - & 29.50 & - \\
\hline Spectrum 5 & 76.33 & - & 23.67 & - \\
\hline Spot 6 & 73.84 & 3.40 & 21.36 & 1.40 \\
\hline Spot 7 & 91.73 & 1.76 & 4.86 & 1.65 \\
\hline Spot 8 & 92.70 & 1.68 & 3.87 & 1.75 \\
\hline Spectrum 9 (main oxide scale) & 73.58 & - & 26.42 & - \\
\hline Spectrum 10 (main oxide scale) & 52.21 & 35.44 & 11.94 & 0.41 \\
\hline Spectrum 11 (main oxide scale) & 53.36 & 34.83 & 11.80 & - \\
\hline Spot 12 (continuous oxide scale) & 56.64 & 28.36 & 9.49 & 5.51 \\
\hline Spot 13 (oxide lump) & 32.86 & 30.45 & 26.97 & 9.46 \\
\hline Spot 14 (Al diffusion zone) & 93.97 & 5.63 & - & 0.40 \\
\hline Spot 15 (substrate) & 98.97 & 0.37 & - & 0.66 \\
\hline Spectrum 16 (upper oxide) & 64.34 & - & 35.66 & - \\
\hline Spectrum 17 (lower oxide) & 62.96 & 1.68 & 32.68 & 2.68 \\
\hline
\end{tabular}

The X-ray patterns of the oxidized samples are gathered in Figure 6. According to the depth probed with the X-rays, the uncoated DADI steel grows mostly $\mathrm{Fe}_{2} \mathrm{O}_{3}$ oxides after oxidation. This agrees with the EDS composition of the uppermost scale (Table 2). $\mathrm{Fe}_{2} \mathrm{O}_{3}$ is also unambiguously detected in the aluminized samples in addition to some reflections of the $\mathrm{FeAl}_{2} \mathrm{O}_{4}$ spinel oxide. However, the main peaks are here associated with a bcc structure. These bcc reflection can be related to the originally formed $\mathrm{B} 2-\mathrm{AlFe}$ and to an $\alpha-\mathrm{Fe}(\mathrm{Al})$ phase. The EDS in the cross-section show indeed that the coating areas under the oxide nodules have undergone diffusion towards the substrate while some other areas still contain $25 \mathrm{wt} \% \mathrm{Al}$ in line with the B2-AlFe phase. 


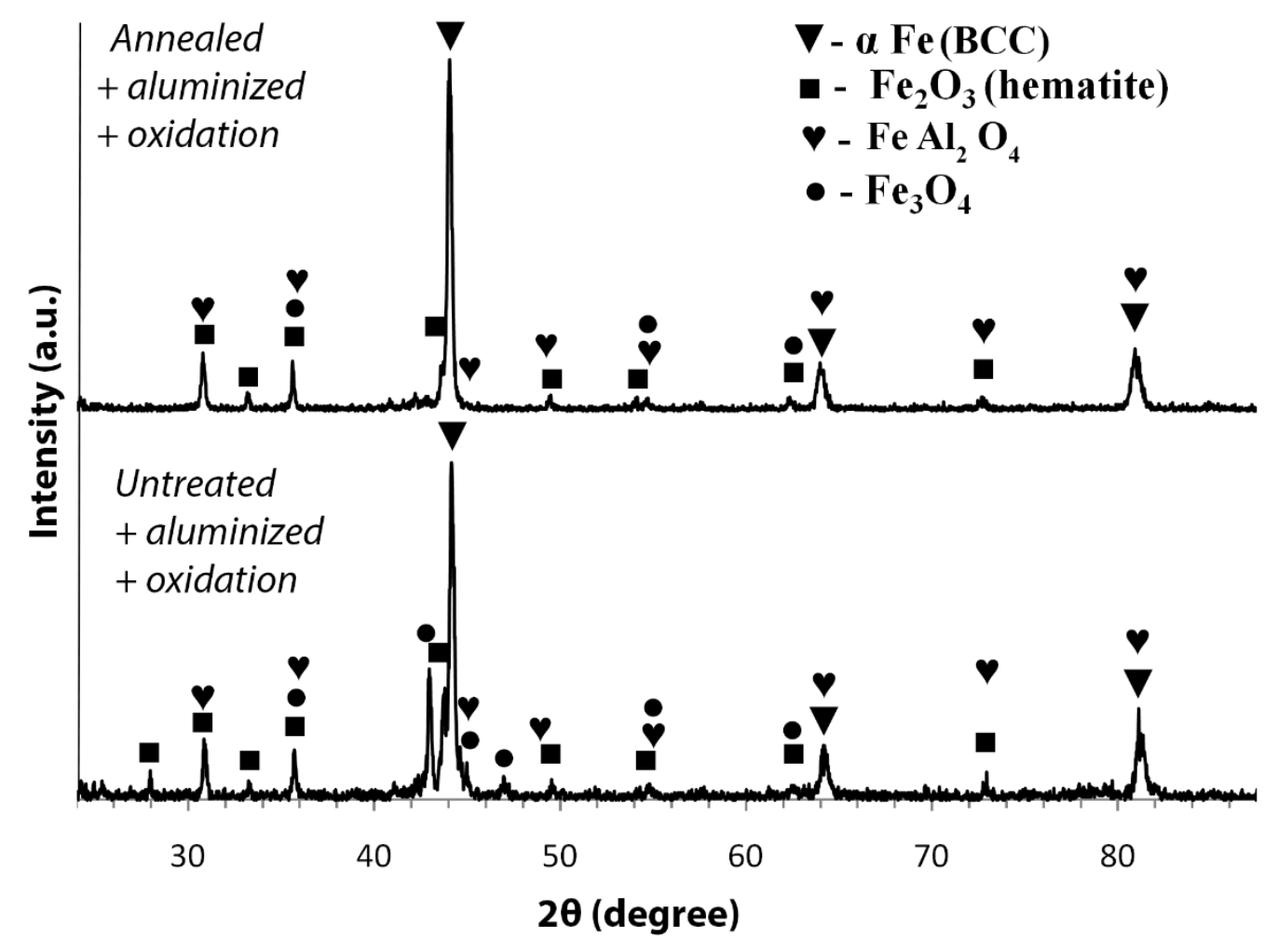

FIGURE 6. XRD patterns of the aluminized treated and untreated DADI samples after oxidation in air at $650^{\circ} \mathrm{C}$ for $100 \mathrm{~h}$.

\section{DISCUSSION}

\subsection{Slurry aluminization of DADI steel}

Slurry aluminization using aqueous suspensions with $\mathrm{Al}$ microparticles can be considered as a mixed situation between the substrate dissolution by molten $\mathrm{Al}$ and the subsequent solid state diffusion. The first step is accompanied by a local elevation of temperature resulting from the highly exothermic reaction between $\mathrm{Al}$ and $\mathrm{Fe}[9,10]$. Therefore, the aluminide coating is often formed much faster than by CVD-related techniques [18] and the growth of the intermetallic coating layers can be better controlled than by hot dipping, which are strongly dependant on the substrate chemistry [19]. In this work, the same mechanisms seem to occur whereby with the increase of temperature molten $\mathrm{Al}$ is released when the oxidized peripheral shells of the particles break down [20]. When molten $\mathrm{Al}$ gets in contact with the substrate, two phenomena occur. The first one is in line with the rapid dissolution of metal atoms that allows the $\mathrm{Fe}_{\mathrm{x}} \mathrm{Al}_{\mathrm{y}}$ to grow by self-propagating high temperature synthesis [9] as far as Al keeps on being supplied from the slurry. Then, solid state interdiffusion occurs favoured by the very defective $\mathrm{Fe}_{2} \mathrm{Al}_{5}$ structure [21] formed right after the disappearance of $\mathrm{FeAl}_{3}$ with the eutectic composition [9]. 
Due to the high temperature treatment at $900{ }^{\circ} \mathrm{C}$, outward Fe diffusion occurs, which fosters the most thermodynamically stable FeAl phase [22] in most of the coating. The evenness of the diffusion front of the coating towards the substrate could be related to the presence of $\mathrm{Si}$. Indeed, many different authors have reported that Si reduces the rate of diffusion of solid state $\mathrm{Al}$ in iron-based alloys and prevents the uneven growth of $\mathrm{Fe}_{2} \mathrm{Al}_{5}$ [23-27]. The second phenomenon is related to the presence of graphite nodules at the surface. When molten Al gets in contact, no reaction occurs because of the poor wettability of $\mathrm{C}$ by molten $\mathrm{Al}[28,29]$. This implies that $\mathrm{Al}$ reacts along the interface between the metal matrix and the graphite inclusions, and this phenomenon is exacerbated upon oxidation as shown in Fig. 5 and Table 2.

This coating process has been shown to simultaneously oxidize the interface between the slurry and the diffusion coating [30]. Therefore, the slurry residue detaches upon cooling due to the mismatch of the coefficients of thermal expansion (CTE) between the ceramic $\left(\mathrm{Al}_{2} \mathrm{O}_{3}\right)$ bisque and the $\mathrm{Fe}-\mathrm{Al}$ intermetallic diffusion layer developed underneath [31]. Hence, the C-rich thin films observed on the residue side in contact with coating appear to the replica of the graphite inclusions but they are too fine to be analysed accurately with our techniques.

\subsection{High temperature oxidation}

The processes taking place on the surface of the uncoated DADI exposed to the oxidizing atmospheres at elevated temperatures has been previously discussed on cast iron with different morphology of graphite [32]. The authors demonstrated that internal oxidation significantly occurred along the interface between the matrix and the flake-like graphite but not in the spheroidized graphite counterparts. In contrast, graphite readily reacted with the oxygen to result in the volatile $\mathrm{CO}$ and $\mathrm{CO}_{2}$, in particular with increasing temperature [32]. The same phenomenon occurs at reduced oxygen partial pressure [33] like the ones likely encountered in this work at the interface between the metal matrix and the nodules. The cavities left behind can be readily occupied by the bulky iron oxides [7,18]. The mass loss by decarburization of the alloy is thus balanced by the significant growth of the iron oxides. Therefore, any attempt to calculate a kinetic law would be inappropriate.

A very similar situation occurs for the aluminized specimens. In contrast, the growth of the $\mathrm{Al}$ and $\mathrm{Fe}$ oxides is much limited and this allows to observe some of the mass losses at the beginning of the oxidation in the as-received and non-annealed DADI. Although we did not investigate these particular samples after short oxidation times, one can hypothesize that some 
flake-like graphite was present in the non heat-treated samples compared to the heat treated ones because the selected annealing fosters spheroidization of graphite [4]. In agreement with the findings of Lin et al., the flake-like graphite would induce faster oxidation and decarburization [32]. In contrast, the graphite-free areas of the coating undergo a more conventional oxidation [34] whereby the initial $\mathrm{Fe}_{2} \mathrm{O}_{3}$ formed is superseded by the growth of protective $\mathrm{Al}_{2} \mathrm{O}_{3}$ with time and/or temperature [35]. Nevertheless, the exposure at $650^{\circ} \mathrm{C}$ for 100h has brought about $\mathrm{Al}$ inward diffusion. The $\mathrm{Al}$ content in the coating thus falls below a critical $\mathrm{Al}$ threshold whereby no more $\mathrm{Al}_{2} \mathrm{O}_{3}$ can be sustained and therefore $\mathrm{FeAl}_{2} \mathrm{O}_{4}$ and $\mathrm{Fe}_{2} \mathrm{O}_{3}$ form. Critical $\mathrm{Al}$ concentrations of $3.5 \mathrm{wt} \% \mathrm{Al}$ have been proposed in pack and CVD aluminized ferritic-martensitic and austenitic steels for resistance in wet air at $650^{\circ} \mathrm{C}$ by Pint and Zhang [36]. This is in line with the depletion of Al observed by EDS under the oxide scale (Table 2). Furthermore, the thickness of the coating with this heat treatment does not allow to fully cover the graphite nodules and to establish a sufficiently even coating, which results in very limited oxidation resistance.

\section{CONCLUSIONS}

Compared to the uncoated DADI, the $10 \mathrm{mg} / \mathrm{cm}^{2}$ slurry aluminization lowers markedly the oxidation at $650^{\circ} \mathrm{C}$ for $100 \mathrm{~h}$ in air. This results in a reduction of the oxide scale by about $70 \%$. However, the oxide scale is insufficiently protective after $100 \mathrm{~h}$ of exposure because of the formation of $\mathrm{Fe}_{2} \mathrm{O}_{3}$ and the insufficient coverage of the coating on the graphite nodules. Therefore, further investigations should be carried out by increasing the overall slurry amount and by Ni-plating the surface prior to slurry aluminization.

\section{ACKNOWLEDGEMENTS}

The authors gratefully acknowledge the financial support of the European Commission in the project "Production of Coatings for New Efficient Clean Coal Power Plant Materials", POEMA, Grant agreement 31043 (FP7-NMP) and the intellectual support of all partners. Also, many thanks to the University of La Rochelle (France) for providing of co-founding and financing Olga Tsurtsumia's secondment to the Laboratoire des Sciences de l'Ingénieur pour l'Environnement (LaSIE). 


\section{REFERENCES}

1. R.Elliott: Cast Iron Technology, Butterworths, London, 1988, pp.672.

2. M.Bauccio: ASM Materials reference book, $3^{\text {rd }}$ ed., ASM International, USA, 1993, pp.620.

3. Joseph R Davis: ASM specialty hand books, Cast Irons, USA, 1996, pp.494.

4. E.Kutelia, N.Khidasheli, O.Tsurtsumia, G.Beradze: Procedia Eng., 2010, vol. 2, pp.1219-1224.

5. E. Kutelia, N. Khidasheli, G. Beradze, T. Dzigrashvili, D. Butskrikidze: NACE-Corrosion 2008, Paper \#08113. New Orleans, USA, 2018.

6. X. Wang, Y. Fan, X. Zhao, A. Du, R. Ma, X. Cao: Metals 2019 vol. 9, pp. 648.

7. A.R. Kiani Rashid, D.V. Edmonds: Surf. Interface Anal., 2004, vol. 36, pp. 1011-1013.

8. F. Pedraza, M. Mollard, B. Rannou, J. Balmain, B. Bouchaud, G. Bonnet: Mater. Chem. Phys., 2012, vol. 134, pp. 700-705.

9. M.C. Galetz, X. Montero, M. Mollard, M. Günthner, F. Pedraza, M. Schütze: Intermetallics, 2014, vol. 44, pp. 8-17.

10. F. Pedraza, M. Proy, C. Boulesteix, P. Krukovskyi, M. Metel: Mater. Corros., 2016, vol. 67, pp.1059-1067.

11. B. Bouchaud, B. Rannou, F. Pedraza: Mater. Chem. Phys., 2013, vol. 143, pp. 416-424.

12. C. Boulesteix, F. Pedraza: Surf. Coating Technol., 2018, vol. 339, pp. 27-36.

13. M. Zamanzade, A. Barnoush, C. Motz: Crystals, 2016, vol. 6, pp. 1-29.

14. B.Rannou, F.Velasco, S. Guzman, V. Kolarik, F. Pedraza: Mater. Chem. Phys., 2012, vol. 134, 1, pp. 360-365.

15. H. Okamoto: ASM Handbook Vol 3: Alloy Phase Diagrams, ASM Int., The Materials Information Society, Materials Park, Ohio, USA, 1992, pp. 800.

16. X. Li, A. Scherf, M. Heilmaier, and F. Stein: J. Phase Equilib. Diffus., 2016, vol. 37, pp. $162-173$.

17. V. B. Trindade, R. Borin, B.Z. Hanjari, S. Yang, U. Krupp, H-J. Christ: Mater. Res., 2005, vol. 8 , pp. 365-369.

18. V. A. Ravi, T. K. Nguyen, J. C. Nava: Aluminizing of steel to improve high temperature corrosion resistance, in E.J. Mittemeijer and M.A. Somers (Eds.), Thermochemical surface engineering of steels, Woodhead Publishing. Woodhead Publishing Series in Metals and Surface Engineering, No. 62, 2015, pp. 751-767.

19. R.W. Richards, R.D. Jones, P. D. Clements, H. Clarke: Intnal. Mater. Rev., 1994, vol. 39, pp. 191-212.

20. F. Pedraza, R. Podor: Mater. Charact., 2016, vol. 113, pp. 198-206. 
21. L.Levin, A. Ginzburg, L. Klinger, T. Werber, A. Katsman, P. Schaaf: Surf. Coating. Technol., 1998, vol. 106, pp. 209-213.

22. A. Kostov, B. Friedrich, D. Živković: J. Min. Metall., Sect. B, 2008, vol. 44, pp. 49-61.

23. M-B. Lin, C-J. Wang: Surf. Coating Technol., 2010, vol. 205, pp. 1220-1224.

24. M-B. Lin, C-J. Wang, A.A. Volinsky: Surf. Coating Technol., 2011, vol. 206, pp. 15951599.

25. S. Kang, K. Han, K. Kim, Y. Kang, K.Son, D. Kim: ISIJ Int., 2012, vol. 52, pp. 1342-1347.

26. R. Mola, W. Depczyński: Arch. Foundry Eng., 2014, vol. 68, pp. 20-23.

27. R. Mola, T. Bucki, K. Wcisło: Arch. Foundry Eng., 2014, vol. 14, pp. 85-90.

28. K. Landry, S. Kalogeropoulou, N. Eustathopoulos: J. Mater. Sci. Eng. A, 1998, vol. 254, pp. 99-111.

29. 36. D. Zhang, D-Y. Zhu, T. Zhang, Q-F. Wang: Trans. Nonferrous Met. Soc. China, 2015, vol. 25 , pp. 2473-2480.

30. C. Boulesteix, F. Pedraza: Surf. Coat. Technol., 2018, vol. 339, pp. 27-36.

31. Y.S. Touloukian, R.K. Kirby, R.E. Taylor, T.Y. Lee, Thermophysical properties of matter, Thermal Expansion Nonmetallic Solids, 13, Plenum Press, New York, 1977, p. 176.

32. M-B. Lin, C-J. Wang, A.A. Volinsky: Oxid. Met., 2011, vol. 76, pp. 161-168.

33. E. A. Gulbransen, K. F. Andrew, F. A. Brassart: J. Electrochem. Soc., 1963, vol. 110, pp. 476-483.

34. B. Pöter F. Stein, R. Wirth, M. Spiegel: Z. Phys. Chem., 2005, vol. 219, pp. 1489-1503.

35. F. Pedraza, J.L. Grosseau-Poussard, J-F. Dinhut: Intermetallics, 2005, vol. 13, pp. 27-33.

36. B. A. Pint, Y. Zhang: Mater. Corros., 2011, vol. 62, pp. 549-560. 